\title{
Chapter 12 \\ Fathers on Leave Alone in Switzerland: Agents of Social Change?
}

\author{
Isabel Valarino
}

\subsection{Introduction}

Switzerland has a delayed and limited welfare state, which differs greatly from its continental European neighbors (Castles and Obinger 2008). This is especially true in the field of family policies for parents' leave entitlements. While a federal maternity insurance of 3.5 months was adopted only a decade ago, to this day there is no statutory right to parental or paternity leaves. Employed fathers are currently not considered as caregivers by the Swiss state. According to a recent comparison of 35 industrialized countries (Moss 2014), this is an exceptional situation; men usually have access to parental leave and sometimes to paternity leave too.

This context affects parents' lives dramatically. Longitudinal and representative data for Switzerland show that transition to parenthood is a crucial event that shapes men's and women's lives in gendered ways (Giudici and Gauthier 2009; Levy et al. 2006; Widmer et al. 2003). Even couples who intend to share paid and unpaid work equally do not manage to put into action these intentions once the first child is born (Bühlmann et al. 2009; Le Goff et al. 2009). In 2013, among couples with at least one child under the age of $6,29.3 \%$ had a male breadwinner model and $49.3 \%$ had a modified version of this model, where the father worked full-time and the mother worked part-time (FSO 2013a).

Theoretically, these inequalities are understood as resulting from social processes taking place at different societal levels: the institutional, interactional, and individual levels (Risman 1998, 2004, 2011). On each of the levels of this "gender structure," social mechanisms tend to operate a differentiation between fathers and mothers, and organize unequal relations on the basis of these presumed differences.

I. Valarino $(\square)$

Institute of Social Sciences, University of Lausanne,

Géopolis Building, CH-1015 Lausanne, Switzerland

e-mail: Isabel.Valarino@unil.ch; isabel.valarino@sociology.su.se 
This research focuses on how some fathers adapt to the institutional context and manage to find individual paths to leave uptake. For this purpose, 13 pioneer men who had taken at least 1 month of leave from wage work-in whatever form or setting - in order to care alone for their child were interviewed.

The study analyzes the implications of leave uptake for the social construction of parenthood. Thus research in other countries has shown that leave uptake has the potential to reduce the specialization of roles in the transition to parenthood, and to prompt father involvement (e.g., Haas and Hwang 2008; Rehel 2014; Wall 2014). In this study we explore how leave uptake is experienced in the Swiss context, and its implications for fatherhood and gender equality.

\subsection{The Swiss Leave Policy Context}

Switzerland only introduced a federal maternity insurance at the beginning of the $21^{\text {st }}$ century. While the principle was accepted by the electorate in 1945,60 years of political negotiations were needed before a law was implemented in 2005 (FCWI 2001, 2011; Valarino 2014a). Employed and self-employed women are now entitled to a 14-week maternity insurance, paid at $80 \%$ of the salary. Two additional weeks can be taken without pay, although many employers compensate them (Valarino 2014b).

The slow development of leave policies in Switzerland-and of the Swiss welfare state in general-is mainly due to its political institutions (Armingeon 2001; Obinger et al. 2005). Switzerland is a federal state and has a direct democracy, which means that a broad consensus must exist among the electorate and cantons for a law to be introduced. Furthermore, Switzerland is not part of the European Union, which implies it must not conform to EU directives, notably the one on parental leave (European Union 2010). As regards political forces, the right wing has been historically strong in Parliament, and is currently against implementing statutory paid parental or paternity leaves (FCWI 2014; Obinger 1998). Attitudinal factors are also important: the liberal ideology is strong in Switzerland, and there is a reluctance in the population regarding state regulation of what is considered as the "private sphere" (Armingeon 2001; Pfau-Effinger 2008). Finally, gendered representations of parenthood are still widespread; mothers are considered the main and legitimate caregivers for a child (Bühlmann et al. 2009; Levy et al. 2002).

Within this context, and as a consequence of the late adoption of a federal maternity insurance, there exists no statutory parental or paternity leave in Switzerland. Employed fathers may be granted short paid paternity leave by their employers through company regulations or collective labor agreements. These leaves are usually 1 or 2 days long, and comparable to leave granted in the cases of marriage or house moving. More rarely employers grant 1 or 2 weeks and up to 1 month of leave. The possibility to take an unpaid parental leave sometimes also exists. However, these company-based entitlements only concern a minority of workers in Switzerland. A recent government report estimated that in 2009, $27 \%$ of individuals 
submitted to collective labour agreements (only half of the employed population) had access to a paternity and/or a parental leave entitlement (FSIO 2013). Among work organisations, public administrations are clearly more generous (Canning Wacker and Dalla Palma 2005; SECO and FSIO 2012).

Since the adoption of a minimal leave scheme for mothers, a window of opportunity for parental and paternity leave supporters has opened. From 2006 to 2013, no less than 25 parliamentary proposals were submitted, yet without success to this day. While this indicates an increasing political concern about fathers' access to a statutory leave and involvement in childcare, leave proposals do not systematically take into account gender equality objectives (Lanfranconi and Valarino 2014; Valarino 2014a).

\subsection{Theoretical Framework on Fatherhood}

This study draws on Risman's $(1998,2004,2011)$ conceptualisation of gender as a social structure. Gender relations and parenthood are understood as being shaped by mechanisms taking place at the institutional, interactional, and individual societal levels. These social mechanisms tend to operate a differentiation between men and women - and between fathers and mothers - and to organize unequal relations on the basis of these presumed differences. At the institutional level, social policies, laws and organizational rules often distribute resources and opportunities in gendered ways. The Swiss leave scheme illustrates well how the state attributes childcare responsibility to mothers only. At the interactional level, individuals' parenting practices can be understood as situated conducts conforming to gendered expectations of behavior (West and Zimmerman 1987). For instance, in the work environment men may face the assumption that fatherhood is only about financial provision for the family (e.g., Burnett et al. 2012; Hojgaard 1997). Finally, at the individual level, socialisation mechanisms and circulating discourses influence individuals' gender identities and their conceptions of motherhood and fatherhood (e.g., Lupton and Barclay 1997).

Of particular relevance for this study is the way fatherhood is constructed in relation with motherhood; i.e., interviewees' representations of fathers' and mothers' roles as well as their practices and involvement in childcare with respect to their partners' (Nentwich 2008). This construction is seen as the object of negotiations taking place in the couple as well as in the workplace and as being shaped by institutional and cultural factors (Levy et al. 2002; Lupton and Barclay 1997).

Following Risman's $(1998,2004,2011)$ conceptualization, the three levels of the gender structure are interconnected. While they usually reinforce each other to maintain gender differences and inequalities, changes taking place at one level of the gender structure can potentially challenge gender relations on the other levels. Change toward more gender equality is defined as any social mechanism that, for example, reduces differentiation between fathers' and mothers' conception of the self, reduces gendered expectations within social interactions, or reduces the 
specialization of tasks and roles between parents that usually takes place at the transition to parenthood. The study explores the ways in which men's leave uptake in a home alone manner may trigger social change on these different levels.

\subsection{Past Research on Men's Use of Leave Policies}

In countries with decades of experience with leave policies, empirical studies have been conducted on men's use of leave, and on the effects for parenthood and gender relations. Scholars find that fathers' leave uptake-from 2 weeks or more-has positive effects on their subsequent involvement in childcare (for Sweden, see Haas and Hwang 2008; for a comparison of four OECD countries, see Huerta et al. 2013; for the US, see Nepomnyaschy and Waldfogel 2007; Pleck 1993; for the UK, see Tanaka and Waldfogel 2007). The existence and use of such leaves at the institutional level therefore decreases the gendered division of childcare work at the interactional level. To a certain extent, it also modifies fathers' identities at the individual level (for Norway, see Brandth and Kvande 2002; for Canada and US, see Rehel 2014; for Portugal, see Wall 2014).

Research on leave policies in Switzerland focused mainly on the political process that led to maternity insurance implementation (see Aebi et al. 1994; Dafflon 2003; Leimgruber 2010; Studer 1997) and on the current status of leave policies in parliament (Häusermann and Kübler 2010; Lanfranconi and Valarino 2014). Understandably, in the absence of statutory federal parental and paternity leaves, men's experiences of leave have barely been analyzed in the Swiss context. In a qualitative research on men's use of company-based leave entitlements, Brandalesi (2010) analyzed the experience of four fathers who had taken short paternity leaves of 1 or 2 weeks. She observed that paternity leave uptake was not perceived by fathers as a transgression of gender norms, but more so as an opportunity to establish a relationship with the child. Furthermore, the division of childcare work remained gendered among parents.

More recently a mixed-methods case study was conducted on paternity leave implementation in a public company (Valarino 2014a; Valarino and Gauthier 2015). It revealed that the 1-month leave had limited gender equality effects on fatherhood representations and practices. On the one hand, it enabled fathers to participate in family life, learn to perform childcare activities and to appropriate their fatherhood identity. On the other hand, the majority of fathers mainly had a secondary and temporary role with the child, while mothers were the central parent. Interestingly, five of the 22 fathers interviewed used paternity leave to care for their child alone on a part-time basis. In these cases, the gendered division of work during the leave was more concretely challenged than for those who had taken the leave in the copresence of the mother. The present study follows up on these results and develops this topic in more depth. 


\subsection{Presentation of Data and Methods}

\subsubsection{Data Collection}

The data was collected in the frame of two different research projects. Five interviews stem from the above-mentioned case study conducted in 2012 on paternity leave in a public sector company (Valarino 2014a). Interviews addressed fathers' leave negotiation at work, their leave experience and their fathering practices. A pilot interview conducted in 2011 for this research is also included in the sample. In addition, seven new interviews were conducted in 2014 for the present study. Participants were found by snowball sampling technique, by activating professional and personal networks.

The call for participation invited men who had been on leave for a minimum period of 1 month to care alone for their child or children aged below 3 years old, in order to share their leave experience and their current work and family life organization. Since there existed no statutory leave for men in Switzerland and therefore no clear definition of "being on leave", an encompassing approach was adopted. Not only fathers who had taken a "paternity" or "parental leave" designated as such by their employer, but also those who had taken vacation or who had used other means, were invited to participate in the study. Interviews lasted between 1 h30 and 2 h30 and took place at participants' homes, workplaces or in cafés. They were recorded, transcribed and anonymized; i.e., names, companies, and cities were replaced with pseudonyms.

\subsubsection{Methodology of Analysis}

Thematic analysis, "a method for identifying, analyzing, and reporting patterns (themes) within data" (Braun and Clarke 2006, p. 79), was used to analyze interview transcriptions. The present study focuses mainly on the "semantic" or "explicit" level of the data (for a distinction with the "latent" or "interpretive" level, see Braun and Clarke 2006), describing how respondents make sense of their decision to take a leave in order to care alone for their child, how they experienced the leave and how they perceive it may have impacted their fathering practices, couple relationship and work life. However, the themes identified are also contextualized within the broader structural context that shapes individuals' experiences.

Methodologically, themes were identified through the coding process of the interviews, performed with computer-assisted qualitative data analysis software. Throughout the analysis, portions of each transcription were coded, labeled and organized hierarchically in order to achieve a stable coding grid and to make sense of interviewees' experiences. In addition to analyzing these codes, individual summaries for each respondent were outlined, in order not to lose sight of how leaves fit into specific life trajectories. 


\subsubsection{Sample Characteristics}

As a consequence of the Swiss policy context and considering the recruitment process adopted, the respondents differ from the population in several aspects. For instance, almost half of them are cohabiting (see Table 12.1). This is a much higher proportion than the percentage of births out of wedlock; $21 \%$ in 2013 (FSO 2013b). Due to conservative views on the family and institutional barriers, marriage is the predominant union type that accompanies the transition to parenthood in Switzerland (Le Goff and Ryser 2010). About half of the respondents are first-time fathers (7 out of 13) and three were expecting a second child at the moment of the interview. Three couples have two children, two have three children and one has five children. Children living in the households are aged between 10 months and 13 years old. Respondents are aged between 27 and 44 years old.

Another key distinction of the sample is the couple's division of paid work. While the predominant family models in Switzerland are clearly gendered (FSO 2013a), half of couples in the sample are dual part-time earners. In 2013, this model concerned only $6.2 \%$ of the population. Also an indication of the sample's specificity is the fact that it mainly counts highly educated individuals among respondents ( 9 out of 13 interviewees hold a tertiary degree education), and their partners (11 out of 13). However, because couples have adopted different combinations of working hours and do not have equally financially rewarding jobs, there is a large diversity as regards household incomes. Most fathers (11 out of 13) and their partners (7 out of 13) are working in the public sector. This is partly due to the fact that the case study interviews were conducted in a public sector company.

Finally, it should be noted that there is an over representation of French-speaking individuals in the sample, which is due to the snowball sampling technique. Only three out of the 13 interviewees live in the German-speaking part of Switzerland, which actually represents over $60 \%$ of the residing population (Lüdi and Werlen 2005). While there exist cultural differences between these regions (Bühler 1998, 2001; Bühler and Meier Kruker 2002), they are probably not decisive in this explorative study, as interviewees were pioneers in both contexts.

\subsection{Findings}

\subsubsection{Four Types of Leave Uptake}

Four main types of leave uptake situations were identified: unpaid parental leave; paid paternity leave; career break; and unemployment insurance (see Table 12.1). Leave modalities diverge significantly from one another. The leave length ranges from 4 weeks to 5 years, taken at a full-time or part-time rate. The degree of institutionalization goes from company entitlements with job protection and pay to temporary dropout of the labor market. And the amount of time spent caring alone 


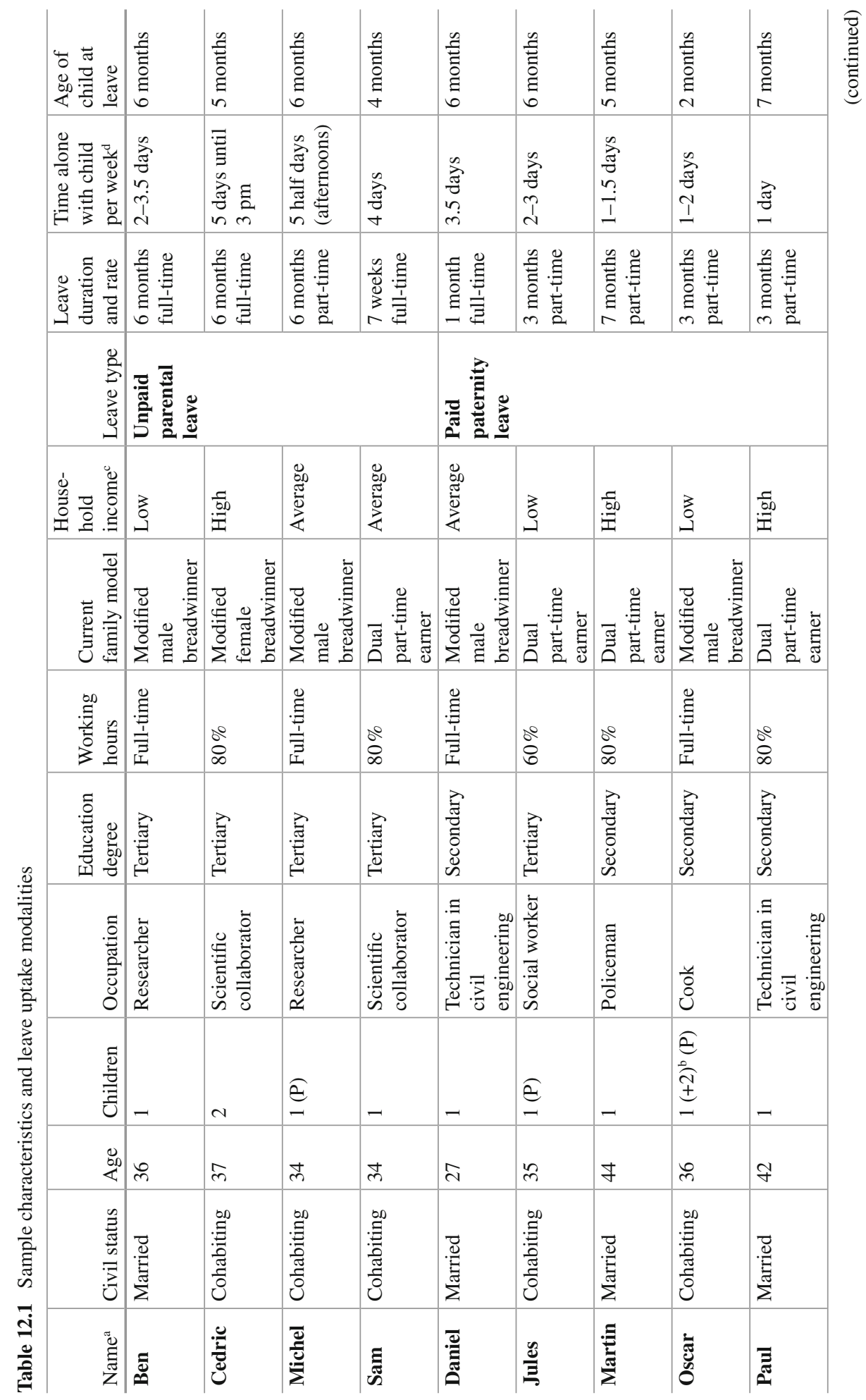




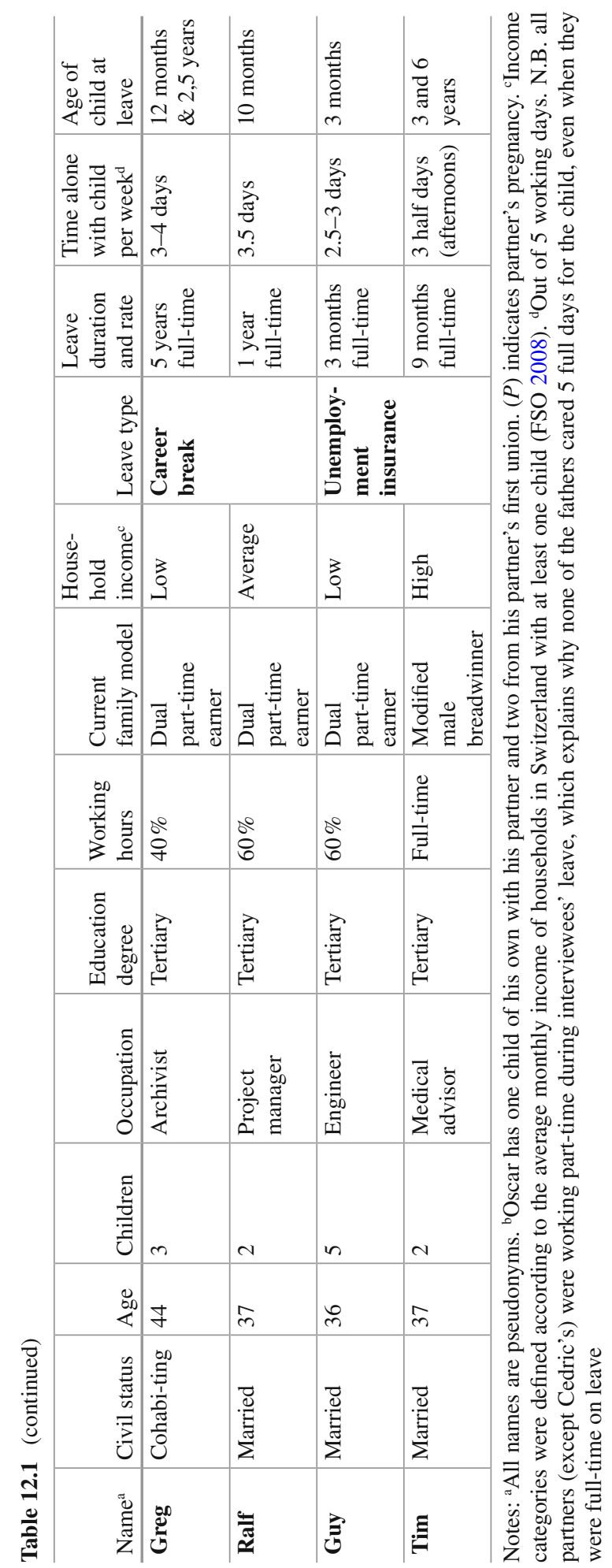


for the child varies significantly: from almost full-time responsibility to 1 day per week only. It is important to note that fathers never cared alone full-time for their child—even when their leave was taken full-time-because all partners (except one) were working or studying at a part-time rate during men's leave and were therefore also present at home during the week.

\subsubsection{Unpaid Parental Leave}

Four interviewees used the unpaid leave granted by their public sector employer for 1,5-6 months. Ben, Cedric and Sam took their leave full-time while their partners were working at a part-time rate ( 2 to 4 days per week). Michel took his leave parttime and cared for his son on afternoons. As the leave was unpaid, the couples considered the financial consequences. They could count on average or high incomes, and the income gap between partners was small at the moment of leave uptake. Respondents took the leave when the child was between 4 and 6 months old.

Their motivation for taking a leave is related to their reflexive approach to fatherhood and gender relations. Sam and Michel report that their parents had an egalitarian family model and that their fathers were very involved in childcare. For Cedric and Ben, it is their educational trajectory and occupational activity that led them to embrace gender equality values. Further reasons were given for taking an unpaid leave, such as concerns about daycare solutions. Ben and his partner Agathe wanted to extend the period of parental care ("She's too young to be in strangers' arms" said Ben), and Cedric and Clara were afraid of not finding an available place in due time. Partners' resources - their education, income and/or career prospects—also played an important role in respondents' decisions. Cedric's leave coincided with a career opportunity Clara seized. Sam's partner Selma got pregnant shortly after starting a new job, therefore they decided she would limit her time off work to the minimum.

The four respondents are forerunners in their work place: few or even none of their male colleagues had taken a similar leave before them. With the exception of Cedric, interviewees received their direct supervisors' support and did not face any obstacles. Ben and Michel report some uncertainty regarding the administrative procedure and the extension of their fixed-term working contracts. In the context of some difficult work relationships, Cedric was subject to harsh criticism ("They even told me 'It's a form of betrayal of the lab"'). Reactions were overall positive and supportive among friends and family, reflecting to a certain extent shared values about gender equality. However, Ben's family members were surprised and expressed concerns about his abilities to care alone for his child, revealing gendered representations of parenthood. 


\subsubsection{Paid Paternity Leave}

Daniel, Jules, Martin, Oscar and Paul work for the same local public administration. They took some of the paternity leave they were entitled to-21 paid days to take within the child's first year-in a home alone manner. Daniel took his leave fulltime when his son was 6 months old. The others took leave part-time: they used leave days punctually over several months. In the cases of Jules, Martin and Paul, paternity leave was a transition tool before the official start of their part-time work. During leave, interviewees' partners were working at a rate between 50 and $80 \%$. No financial considerations influenced men's leave uptake decision; the leave was fully compensated.

The motives of interviewees for leave uptake are a desire to involve in the daily care of the newborn child and to develop a close relationship with him or her. Daniel explains his decision as a reaction to his own father, who disappeared from his life when he was very young: "It's clear I'm not going to reproduce what I experienced". Other respondents considered the leave as a childcare solution, a "safety valve" as Jules put it.

Overall, the use of paternity leave was well received by their supervisors and colleagues, especially when respondents had independent functions and could anticipate their workload. There was one exception: Oscar experienced strong disapproval from his supervisor, who had to hire an auxiliary cook to replace him once a week during his leave. Respondents report positive, but also surprised reactions and sometimes envy from friends and family. They considered themselves privileged in comparison with private sector employees.

\subsubsection{Career Break}

Two interviewees in the sample took a career break: Ralf took a year off when his first child was 10 months old and Greg stayed 5 years at home when his two elder children were 1 and 2,5 years old (a third child was born after 3 years of leave). During their leave, interviewees' partners were the sole breadwinners. They worked between 70 and $80 \%$ and were at home with the family 1 or 1,5 days per week. As they had tertiary education degrees, they could count on average incomes. However, Greg and Sally experienced financial hardship as they had two children already.

The circumstances of Ralf's and Greg's leave uptake differ greatly. It was chosen for Ralf: he resigned from his job and decided to "try the experience of staying at home" and "not follow the standard model." It was by accident for Greg: he had a severe accident that kept him in the hospital and then at home for over 6 months. Sally increased her participation in paid work and at some point the couple decided to keep this setup for the long term.

In contrast with the previous two leave types, men on career break seem to face more social pressure. Ralf reports that in his work environment, resigning from his job to be a stay-at-home dad was viewed as "incomprehensible, just weird!". 
Greg's family members, who hold traditional family values, thought that "something was wrong with [him]." Respondents were sensitive to these reactions, but they were also comforted in their decision by friends with similar alternative family models.

\subsubsection{Unemployment Insurance}

This leave type is similar to a career break, but it implies receiving unemployment benefits. Guy had just finished his studies in engineering when he became a father and he was registered at the unemployment insurance office until his child was 6 months old. He cared for his child alone for 3 months when his wife Jenny, a university student, returned to classes. Tim took a 9-month leave between two jobs while his wife was working full-time. His children were 3 and 6 years old and they were attending daycare and nursery at a part-time rate. Tim received unemployment benefits at some point during his leave. However, he revealed this information with reluctance and only towards the end of the interview, which suggests he may have feared being stigmatized and/or accused of abusing the social security system.

Tim and Guy both had the desire to be involved fathers. Tim grew up in a gender egalitarian family and was also inspired by the German (his country of origin) parental leave system: "I knew that in Switzerland there are only these limited days of paternity leave, so you have to take it somehow in a private setting, between two jobs, ideally." Tim also mentions that he wanted to support his wife's career and that the timing was appropriate for him, as he wished to reorient his career from research to industry. In the case of Guy, the leave experience was a coincidence due to the fact that he was just starting to look for a job at that time: "Honestly, the first three months, I wasn't in a hurry to find a job."

Respondents report positive and supportive reactions to their leave experience from their family and friends. Leave uptake was actually subsumed by their job search. For Tim, his leave "was never really a subject" he discussed with his former colleagues, as they mainly interpreted it as a period to prepare his next career move.

\subsection{Leave Experience}

While fathers faced substantial differences in their leave uptake situations, many had similar experiences as regards the activities they performed and the difficulties they encountered.

\subsubsection{Intensive Care Work}

The majority of respondents were responsible for a child below the age of 1 year during their leave. All reported doing intensive care work from morning on, which involved changing, dressing, feeding and playing with the baby. Martin and Sam 
were also in charge of feeding the child at night, in order to let their partners sleep. Being the main care provider required "a constant attention" for Cedric and was "even more demanding than being at work" according to Oscar. Fathers' daily routines were paced by the child's eating and sleeping schedule, as well as by very frequent walks outdoors.

I woke up in the morning, had breakfast, I knew more or less his schedule of naps, at night etc. so I woke up on purpose before [...] to make sure to be ready. And when he was awake, I fed him, and then we were mostly outside... (Daniel, technician in civil engineering, 27)

There were differences among fathers as regards the amount of intensive care performed, depending on the length and rate of the leave and the time alone spent with the child. However, all respondents emphasized that caring alone for their child involved much more responsibility and attention than in the co-presence of their partner.

Everything rests on your shoulders. When you're alone, you cannot rely on someone, on the mother, if you have a problem. You really have to take $100 \%$ responsibility for the child. You cannot forget anything. (Cedric, scientific collaborator, 37)

\subsubsection{Social Childcare Time}

For many respondents, leave uptake also had a social dimension. For instance, Ben and Ralf paid visits to their parents or parents in law with their child. Sam, Ralf, Paul and Michel organized joint activities with friends and their children during their leave.

With a friend who also has children, but a bit older, we looked after them together on Wednesday afternoons. We tried to be several [friends]. People started showing up from 5 $\mathrm{pm}$, but we met around 2 or $3 \mathrm{pm}$. [...] My conception of having children and caring for them is not necessarily being alone with them. (Michel, researcher, 34)

Contrary to Michel, Ralf and Sam mainly met with female friends and report having missed male friends during their leave. In the case of Guy, Martin and Sam, as their child was still breastfed, they visited their partner at work or over lunch. Finally, Ben, Ralf and Sam report that toward the end of their leave they brought their child punctually to the daycare structure she or he would soon join for the adaptation process.

\subsubsection{Household Tasks}

The majority of respondents understood their leave duties as going beyond childcare activities and encompassing household tasks such as cleaning, cooking and shopping. However, there are substantial differences as to the degree they tried and 
succeeded in doing these tasks. Respondents who took a paid paternity leave contributed less than others, as many were only home alone 1 day per week.

There are further exceptions, such as Ben who reports that during his leave it was Agathe who prepared in advance the child's food and their own, which was a source of tension. Finally, Sam explains that he did not manage to do cleaning chores when he was with his daughter.

We cleaned and did the laundry while we were together at home. It was enough, just being with Philis. (Sam, scientific collaborator, 34)

\subsubsection{Personal Time and Work-Related Activities}

Most fathers report they barely found time for themselves during their leave experience. Ben, Sam and Tim managed to have some leisure time, for instance reading, jogging or playing music. Depending on their leave situation, some respondents also dedicated some time to work-related activities. This was the case of respondents on unemployment insurance, who were required to submit job applications, do interviews and attend continuing education classes. Greg and Ralf who were on career break also did some job searching when they decided to re-enter the labor market.

As regards fathers on parental or paternity leave, they do not report having worked during their leave or been pressured to do so by their employer. This can be explained for men on unpaid parental leave by the fact that they had anticipated in advance all aspects of their (fairly long) absence. The fact that they were not receiving any salary during this time also probably played a role. Among paid paternity leave recipients, almost all were on part-time leave, which meant they were present at work every week. And although some pressure was noted by Martin who recalled having been asked by his hierarchy to accommodate work demands if the need would arise, this did not happen during his leave.

Once or twice they tried to remind me that I'm a policeman first and foremost. (Martin, policeman, 44)

\subsubsection{Feelings and Main Difficulties Experienced}

The leave was a very positive experience for all interviewees, which they described with superlatives such as "wonderful" (Oscar), "fabulous" (Guy), "magical" and "almost transcendental" (Ben). Fathers appreciated being able to follow closely the child's development, learning to care for him or her, and adapting to his or her rhythm with no time pressure.

It was great having... being able to match the child's pace during his first months of life. It's something fabulous. Because, you don't sleep well at night, you have a lot of things to learn... gestures you don't know, and being able to sleep in the afternoon and things like that. (Guy, engineer, 36) 
On the other hand, experiencing children's "slow time" and doing intensive care work was for some respondents also source of frustration at the beginning of the leave, as they were unable to do the activities they had planned. Greg and Ralf report that a period of adaptation and acceptance of their new full-time activity was necessary.

You have a lot of fantasies, in the sense that at the beginning you think "Ah that's good, I'm at home, I take care of the children, I can do lots of things I couldn't before... for me.” And then you realize. After a month and a half, you understand that you're at home for the kids, so that the household works, and there's not much time left for you. (Greg, archivist, 44)

Therefore the leave experience inspired a wide range of feelings among respondents and the main difficulties reported were understanding the child's needs and responding adequately to comfort him or her.

You go through all emotions, from amazement and love to despair. (Ben, researcher, 36)

Several interviewees experienced a form of isolation during the leave: they felt like the male exception in a female-dominated environment. As Greg puts it, he was "like a white fly" at the playground. Especially fathers on a career break or on parental leave were frequently reminded of their gender role transgression. Sam realized he was not on an equal footing with his partner in the eyes of the midwife who assisted them. Ralf reports that his presence during the playgroups he attended with his son created feelings of awkwardness and discomfort among the women he encountered.

I had the impression that women, including young ones, almost felt attacked in their domain, or invaded. They didn't really know how to deal with a man who stays at home...

[laugh] (Ralf, project manager, 37)

Guy felt that being a male care provider made him especially accountable for his parenting competences in public spaces. This created feelings of anxiety, for example when he went grocery shopping, as he feared he would be evaluated by others on his abilities to manage his child's cries. However, these feelings disappeared rapidly as he gained experience and confidence.

\subsection{Leave Impact: Parenthood and Gender Equality}

Leave uptake had implications on five dimensions, including respondents' fathering practices, their relationship with their partner and division of work, their parenthood representations, their relationship to work, as well as a societal impact.

\subsubsection{Impact on Fathering Practices}

As the previous section showed, the leave experience enabled respondents to acquire and develop their parenting competences_- to know how the child "works" (Sam) and therefore to feel confident as fathers. This implied notably to know the child's 
eating and sleeping habits, to understand the reasons for his or her cries and to find a way to comfort him or her. For instance, Ben reports severe difficulties putting his daughter Elodie to sleep at the beginning of his leave. His narrative about his discovery of a personal solution_-playing her cumbia music_-shows the important role played by the leave in appropriating his fathering role.

One day I was already feeling desperate about the cries when she should take her nap. [...] And before starting the ritual of heating things, I was holding her in my arms, I held her almost all the time in my arms, and I put on Mexican music, cumbia. [...] So she finished eating, she started yawning, and I thought "Oh no, she's going to start screaming again, I can't take it anymore..." [laugh] And then I rocked her like that, with the rhythm of the music, and all of a sudden I realized she was falling asleep! [laugh] [...] And for the second nap, I did the same [...] And it worked! (Ben, researcher, 36)

The majority of interviewees express that their leave experience impacted their relationship with their child. As Greg puts it: "When you're always, always there, you become the reference person." They were able to develop a close, affectionate and intimate relationship, independently from the mother. Jules suggests that the leave experience was the time during which his attachment to his child grew, with long-term consequences as he decided to reduce his working percentage to $60 \%$.

I think it's a bit like drugs... [laugh] You think it's recreational at the beginning and after a while you realize you need it [...] I wouldn't see myself going back, it would cost me something if for X or Y reason I had to change my life structure. (Jules, social worker, 35)

In particular, some fathers emphasize the importance of remaining involved in the long term (beyond the leave period) in order to maintain the close relationship established. Ben is concerned that since his return to work his relationship with his daughter changed. From the points of view of Paul, Guy and Ralf, it is part-time work that really makes a difference for their father-child relationship. Finally, some fathers (Daniel, Jules, Paul and Tim) consider that the leave did not play a primary role in the father-child relation. They argue they would have found other ways to bond if they had not taken a leave, as being an involved father was a strong desire.

\subsubsection{Impact on Gender Relations and Division of Work}

Some interviewees report that their leave experience increased their recognition of the value of family work and thereby triggered more empathy for their partner. However, the leave experience did not necessarily prompt an egalitarian division of family work in the long term among all interviewees. Some interviewees, such as Paul, are explicit about this.

Well changing diapers, she mostly does it; I do it only on Fridays. And for feeding, she also makes the decisions [...] She's in charge of all this and I follow. (Paul, technician in civil engineering, 42)

In cases where the labour market participation of the couple is gendered, such as Daniel, Oscar and Tim, it is implicit that more time and responsibility is taken by 
the mother than the father for childcare. In six cases-Greg, Guy, Jules, Michel, Ralf and Sam - the narratives about the couple's weekly family organization, together with the actual working hours of both partners, suggest that they have adopted a gender equal division of paid and unpaid work.

These interviewees often highlight the challenges of gender equal parenting practices. Michel's anecdote illustrates how habits formed early after the transition to parenthood may work as a blueprint for the couple's medium to long-term parenting. While Louise was on maternity leave and before Michel's parental leave started, the couple noted that Louise was becoming progressively better than him at calming their son's long lasting cries before sleep. Although Michel was already tired from his workday and although it was hard for the parents to see Lucien cry longer, they decided not to opt for the easy solution and that Michel had to improve his soothing skills with him.

At some point we figured with Louise "If it continues like that... you won't be able to put him to sleep anymore..." And so we forced ourselves... But fortunately [Louise] was there; she really helped me go through with it. He cried for longer for some time, until I had found tricks that worked better with Lucien. But I didn't just abandon this area. It's really something we won after a long battle at that time. (Michel, researcher, 34)

A high degree of reflexivity and will is needed by both parents to fight gendered parenting practices. Guy and Jules also noted the crucial role of their partners, who trust them in their caring abilities and enable them to take solo responsibility for their child.

\subsubsection{Impact on Parenthood Representations}

The leave experience played a part in deconstructing respondents' gendered representations of parenthood. To some extent, they realized that parenting abilities are acquired and not innate; that they depend on the time spent and the experience accumulated by each parent with the child, as the following citation suggests.

She [partner] also had to from one day to the other all of a sudden take care of a child alone. There aren't necessarily reasons for her to be more qualified than me for that. [...] She also had to learn, just as I had to learn. (Jules, 35, social worker)

While such a gender-neutral approach of parenthood is shared by several other respondents (e.g., Ben, Greg, Guy and Sam), the majority of fathers believe nonetheless that there exist differences. Some respondents draw on the physiological dimension of motherhood-pregnancy and breastfeeding — to explain differences in parenting style or parent-child relationships. Paul and Martin refer to the "maternal instinct" of their partners and Tim to her "intrinsic sensitivity" to children's needs. Cedric distinguishes between parenting competences, which according to him need to be acquired by both parents, with the parent-child relationship, which he thinks is stronger for mothers, as the following citation suggests. 
The fact that she saw him coming out of her body, and that I saw that from the outside... I think it does create a difference in the relationship with the child. (Cedric, scientific collaborator, 37)

Differences in parenting style are also noted by Greg, who expresses that while he, as a man, can be the main care provider for his children, he interacts with them differently from his partner. They both tend to engage in typically masculine or feminine activities with them. Finally, further typically masculine typed roles are reported by Martin, Michel and Paul who see their role as fathers-in addition to being present, caring and affectionate-in terms of being play and sports mates for their child.

\subsubsection{Impact on Career Perspectives and Relation to Work}

The majority of respondents report that their leave experience did not have direct negative consequences on their career perspectives. However, in Cedric and Oscar's cases, it created difficult relationships with their supervisors. Ralf considers that his career break probably had some impact on his salary and that "one year of leave makes the re-entry into work life a bit more difficult." The case of Tim is interesting, as he reports that his 9-month leave-which he had indicated on his CV-was assessed positively during a job interview. In contrast, Greg considers that his 5-year career break had irreversible consequences.

It totally ruined my career. Well "ruined," not ruined, but I had to abandon archeology. When you're away five years it's... It's an environment where working at $40 \%$ doesn't exist, it's impossible. (Greg, archivist, 44)

For many interviewed fathers, the transition to parenthood modified the importance they attribute to their work life (e.g., Michel, Oscar, Ben, Cedric, Guy and Greg). The notion of work-life balance has become central and guides their career decisions. Oscar, who works as a cook, was used to family unfriendly working hours; he applied for a job with office hours when he decided to have a child. Ben and Michel report that they will search for a part-time job for their next position"It's my only horizon," as Michel puts it. Other respondents were already sensitive to work-life balance prior to parenthood (Guy, Jules, Sam, Ralf and Tim). Jules had for example re-oriented his career from the bank industry to social work because he disliked the working conditions in his field. Sam was working part-time too, in order to have space for his hobbies.

The characteristics of the sample suggest there is an association between taking a period of leave alone and working at a part-time rate. Eight respondents reduced their working percentage within the first year of life of their first child or were already working part-time before. In two cases, there was a clear relation between the leave experience and the subsequent decision to work at a part-time rate. Martin reports that paternity leave convinced him to ask for a reduction of his working hours; he had used his leave days as a test period for part-time work. Ralf reports 
that it was during his 1-year career break that he decided to work at a low part-time rate, as this citation shows.

The most important result of this year is that after spending one year with my child, that's when the strong desire came to not work much more than $60 \%$. I could no longer imagine spending all my time [laugh] without this person. (Ralf, project manager, 37)

Part-time workers report that being an involved father is tied with career costs, which they are nonetheless ready to accept. In his job search, Guy noticed that asking for a part-time position was considered as a lack of motivation, reliability and efficiency by managers. Jules was also struck by the clear difference in people's perception of working at $80 \%$ or $60 \%$, which was viewed suspiciously.

When I said I'd finally work $60 \%$, the reaction was opposite, like "But, is it enough? But..."

Suddenly, it's funny like one day per week it's admirable, and two days per week it's like...

"But are you really serious about your job?" (Jules, social worker, 35)

Beyond the negative perceptions interviewees faced in their work environments, many of them consider that part-time work concretely prevents them from accessing higher positions. For instance, Greg who currently works $40 \%$ believes his partner's career has priority over his. Guy and Jules, who both work at $60 \%$, emphasize that their focus is currently on their family life, and that their career ambitions are on hold.

\subsubsection{Societal Impact of Men's Leave Uptake}

Finally, leave uptake has also implications on the societal level, as many interviewees perceive themselves as pioneers and aim to advance fathers' leave and father involvement in family life. Firstly, among paid paternity leave recipients, the existence of company-based rights had a legitimizing effect of men's use and access to leave. They considered paternity leave as a new social benefit they were entitled to. For instance, even if Oscar's supervisor criticized his leave pattern, he was determined to use it according to his family needs. Jules also noted that with paternity leave implementation, a change in representations was initiated in the work place, as this citation suggests.

As soon as I announced to my colleagues that we were expecting a second child, it's clear that just as when a woman announces it, everybody thinks "maternity leave," they also think "paternity leave." (Jules, social worker, 35)

These respondents were generally critical of the Swiss leave scheme and considered that all employed fathers should be granted the same rights as them. A similar view was shared by the majority of interviewees, who considered Swiss family policies as being too limited in comparison with other countries. As Greg puts it: "Here we're a bit in pre-history." Respondents considered the state should invest more in family policies and that men should be granted a statutory leave in the form of social insurance. 
Secondly, among other respondents and leave situations, several examples of practices that aimed to challenge gendered social norms of parenthood were identified. For example, by adopting a female breadwinner family model, Greg and Sally were aware of their norm transgression, but nevertheless stuck to their decision: "We told each other 'Let's not give a damn about what other people think, let's continue like this!'" Tim decided to make his involvement in family life visible in the labor market sphere, by indicating in his CV his leave uptake. Cedric was the first male employee to take an unpaid leave in his company. With his case, he helped in the creation of a new regulation that entitles employees who take a leave to benefit from an extension of their fixed-term work contract. Cedric and his partner were proud of this achievement:

We were happy to advance the "cause" [...] So we didn't do it only for personal reasons; there was also an activist side to it. (Cedric, scientific collaborator, 37)

Michel's anecdote also illustrates the activist meaning of leave uptake. During the procedure of the extension of his fixed-term contract, he realized he was being granted an "extraordinary derogation," instead of a contract "prolongation." Michel considered that symbolically, this labeling did not fully recognize fatherhood and leave uptake as a normal practice, but instead stigmatized it. He would have liked to contest it, but his supervisors did not support him in this administrative battle.

I wanted the title to be like that. I was ready to go far in order for it to be recognized this way, because words are important... Otherwise people always get the impression you are granted extra time that is not allowed for others. (Michel, researcher, 34)

Finally, fathers who work part-time also contribute to making fatherhood more visible in the work environment and thereby resist gendered expectations. For example, Guy reports that in his daily professional interactions, he must often remind people that he is not available on a full-time basis.

In work life there's the idea that men should always be available $100 \%$, every day. Trying to make them understand that you don't work every day, and that you can't instantly respond to requests - that's something I often have to repeat. It's not obvious, and depending with whom you work, people don't understand. (Guy, engineer, 36)

\subsection{Discussion and Conclusion}

The study shows that in the Swiss context of a poorly developed and gendered leave scheme, there are four different paths to leave uptake and being "on leave" covers different situations. Interviewees on unpaid parental leave and on paid paternity leave benefitted from company-based entitlements. This reflects the role played by work organizations in shaping fathering practices and granting work-life balance opportunities (Pleck 1993), especially in welfare regimes with liberal traits such as Switzerland. However, the preference for social partner solutions instead of state solutions results in significant inequalities among employees and in limited social benefits (Lanfranconi and Valarino 2014; Mach and Trampusch 2011). Indeed the 
scope and generosity of these leaves is limited: parental leave is not financially compensated and paid paternity leave does not exceed 1 month. Interviewees who took a career break and who used unemployment insurance illustrate even less institutionalized forms of leave. Career breaks are private leave solutions, which entail great financial investment from households and insecurity regarding men's labor market reintegration. Fathers using unemployment insurance as a substitute for a paid parental insurance can be viewed as agentic individuals who through their subversive action contest a state which denies them leave rights. However this leave situation comes with non-negligible consequences, such as job search requirements and uncertainties for planning childcare arrangements and career moves, and possibly also entails stigmatization.

Research shows that leave entitlements that are universal, individual, nontransferable, and with high earnings compensation increase men's uptake rates (Haas 2003; Haas and Rostgaard 2011; Moss 2008; O’Brien 2009). Except for paid paternity leave, which guarantees job security and salary payment, leave comes at a price in Switzerland. Therefore leave uptake by fathers (and even more so in a "home alone" manner) is a rare phenomenon. The study sample suggests that men willing and able to pay the price of leave uptake have an atypical profile. In contrast with national trends (FSO 2013a; Levy et al. 2002), they are more likely to work part-time and to share with their partners the consequences of parenthood. Also, many respondents were at some point in their life-in their family or country of origin, their education or employment spheres-socialized to gender equality values, and to men's leave uptake. Finally — and importantly - the majority of respondents and their partners are highly qualified and can count on educational and material resources. It is therefore noteworthy, when putting into perspective the results of the study, that sampled interviewees were especially prone to adopt gender equal values and parenting practices. Considering the lack of survey data on leave uptake by men in Switzerland, we do not know whether the sample is representative of the larger population of pioneer fathers taking leave in a home alone manner and whether results are generalizable. A limitation and possible bias of the study lies in its recruitment process, which reached mainly professionals and individuals with a higher education. Future research should aim to integrate fathers from the working class, who may also experience leave alone situations, for example after job loss and while being on unemployment insurance.

The first aim of the study was to explore fathers' leave experiences. The analysis suggests leave uptake was overall a very positive but also challenging experience. Interviewees perceived the leave as rewarding as it strengthened the father-child relation as well as the couple relation. It helped respondents appropriate their fathering role. As they did intensive care work, and learned to understand and respond adequately to their child's needs, they became more confident in their fathering competences. Being on leave alone was also a challenging and demanding experience. Especially fathers on career break and on unpaid parental leave felt isolated in what they considered a female-dominated environment. Interviewees' leave uptake situation also determined whether they had to engage in work-related activities. Fathers on career break and unemployment insurance were bound to do some job 
searching, while respondents on unpaid parental or paid paternity leave did not report working during their leave. Company-based entitlements, which provide job security, seem therefore more favorable to fathers than less institutionalized leaves.

The second aim of the research was to analyze the implications of respondents' leave experience for fatherhood and gender equality. Findings reveal a mixed picture regarding fathers' practices and representations. On the one hand, and in line with results of a previous study (Valarino 2014a), it is clear that taking leave alone prompted fathers to take on full childcare responsibility during this time, and therefore challenged the idea of fathers as secondary parents assisting the mother. On the other hand, substantial differences in the weekly solo care time spent were observed among interviewees. Because some fathers took leave part-time and because-in accordance with the Swiss normative model-almost all partners were employed part-time when they returned to work, fathers never cared alone on a full-time basis during their leave.

Furthermore, looking at the long term implications of leave uptake on gender relations, the study shows that only about half of the respondents have adopted an equal family organization, while in the other households the partner is the main responsible for family life. Interviewees with the most intensive leave experiences in weekly solo childcare time and length of leave (Greg, Guy, Jules, Michel, Ralf and Sam), are those who were subsequently the most gender equal. Leave uptake is associated with more father involvement, but the research design does not enable to make causal interpretations, as selection effects cannot be controlled for. It is nonetheless noteworthy that two fathers in the sample perceived that their leave experience had led them to opt for part-time work.

Overall, these findings support studies showing that leave duration matters for men's childcare involvement (e.g., Haas and Hwang 2008; Huerta et al. 2013; Rehel 2014). It also speaks for Brandth and Kvande's (2013) critical assessment of leave entitlements taken in a part-time manner, as they argue it prevents men from spending "slow-time" with their child. It seems however that the path to leave uptake is not determinant: the most gender equal fathers took different leave types. This suggests that being an involved father in Switzerland implies seizing opportunities according to individual situations and available resources. Partner support and shared values in the couple are also of chief importance for achieving gender equality.

Gendered parenthood identities were also only partially challenged. The leave experience contributed to the belief that parenting skills are learned and can be performed equally by men and women, but most fathers were convinced of a stronger mother-child relationship, on the basis of essentialized biological differences. Gendered representations of parenthood were therefore not fully challenged, as the gender binary was not questioned (Nentwich 2008).

Significant implications of the leave experience and more generally of the transition to parenthood on men's identities as workers were observed. All respondents reported a distanced relationship to work and were concerned with finding work-life balance. Many respondents questioned what Acker (1990) described as the ideal male worker norm; i.e., a disembodied individual, fully available for work, and free 
of family obligations. Therefore leave uptake was often combined with part-time work as a long-term solution for being involved fathers - a decision which however entailed non-negligible career consequences.

Finally, the study uncovers implications of fathers' leave uptake on the societal level. Fathers on leave alone can be viewed as agents of social change. On playgrounds and in supermarkets, they play a part in "undoing gender" and transgressing gendered norms of parenthood (Deutsch 2007). Within companies, with their leave uptake and their part-time work, respondents make fatherhood more visible in organizational life and challenge the meaning of masculinity (Burnett et al. 2012; Hojgaard 1997). The leave experience can even take an activist dimension; with the aim to advance gender equality and the social recognition of fatherhood. This dimension is probably linked to the Swiss context, as men are currently not recognized as caregivers by the state. However, similar cases were found in Quebec, where men's leave entitlements are more developed (Tremblay 2014). Altogether, fathers' small-scale transgressive actions can be seen as challenging the institutional level of the gender structure, as conceptualized by Risman (1998, 2004, 2011).

To conclude, this explorative qualitative study on men taking leave alone sheds light on the different types of leave situations that exist in the Swiss context. It shows that in the absence of statutory leave policies for fathers, leave uptake has a high price, which only few are willing and able to pay. The study gives insights in the leave experiences of these pioneer fathers, highlighting the positive experience it represents as well as its challenges. It also analyzes the implications of leave uptake for fatherhood and gender equality, revealing a mixed picture among respondents. While it is clear that leave uptake was not equally transformative for all interviewees, findings suggest it also has a societal impact. Men on leave alone in Switzerland can be viewed as agents of social change contributing to the redefinition of the cultural meaning of fatherhood.

Acknowledgements This study would not have been possible without the financial support of the following institutions: Association des Femmes Diplômées des Universités Suisses, Fondation pour l'Université de Lausanne, Fondation Van Walsem and Société Académique Vaudoise. This publication also benefited from the support of the Swiss National Centre of Competence in Research LIVES - Overcoming vulnerability: life course perspectives, which is financed by the Swiss National Science Foundation. The author warmly thanks participants in the research for their trust and time, the editors of this book for their helpful comments on the chapter, and Professor Laura Bernardi for her support to the research.

\section{References}

Acker, J. (1990). Hierarchies, jobs, bodies: A theory of gendered organizations. Gender \& Society, 4(2), 139-158. doi:10.1177/089124390004002002.

Aebi, A., Dessoulavy, D., \& Scenini, R. (1994). La politique familiale et son arlésienne: l'assurance maternité: celle dont on parle et que l'on ne voit jamais... Genève: Institut d'études sociales. 
Armingeon, K. (2001). Institutionalising the Swiss welfare state. West European Politics, 24(2), 145-168. doi:10.1080/01402380108425437.

Brandalesi, V. (2010). Le congé paternité en Suisse. Représentations et usages des bénéficiaires. (Maîtrise universitaire en sciences sociales, politiques sociales et développement social). Lausanne: Université de Lausanne.

Brandth, B., \& Kvande, E. (2002). Reflexive fathers: Negotiating parental leave and working life. Gender, Work \& Organization, 9(2), 186-203. doi:10.1111/1468-0432.00155.

Brandth, B., \& Kvande, E. (2013, August 28-31). Choice and flexibility in the father's quota. Paper presented at the 11th European Sociological Association Conference, Torino, Italy.

Braun, V., \& Clarke, V. (2006). Using thematic analysis in psychology. Qualitative Research in Psychology, 3(2), 77-101. doi:10.1191/1478088706qp063oa.

Bühler, E. (1998). Economy, state or culture?: Explanations for the regional variations in gender inequality in Swiss employment. European Urban and Regional Studies, 5(1), 27-39. Retrieved from http://eur.sagepub.com/content/5/1/27.abstractN2

Bühler, E. (2001). Zum Verhältnis von kulturellen werten und gesellschaftlichen Strukturen in der Schweiz: das Beispiel regionaler Gemeinsamkeiten und Differenzen der Geschlechterungleichheit. Geographica Helvetica, 56(2), 77-89. Retrieved from Retrieved from http://www.geogr-helv.net/56/issue2.html

Bühler, E., \& Meier Kruker, V. (2002). Gendered labour arrangements in Switzerland: Structures, cultures, meanings: statistical evidence and biographical narratives. GeoJournal, 56, 305-313. doi:10.1023/A:1025904010911.

Bühlmann, F., Elcheroth, G., \& Tettamanti, M. (2009). The division of labour among european couples: The effects of life course and welfare policy on value-practice configurations. European Sociological Review, 26(1), 49-66. doi:10.1093/esr/jcp004.

Burnett, S. B., Gatrell, C. J., Cooper, C. L., \& Sparrow, P. (2012). Fathers at work: A ghost in the organizational machine. Gender, Work \& Organization, n/a-n/a. doi:10.1111/gwao.12000

Canning Wacker, N., \& Dalla Palma, S. (2005). Concilier activité professionnelle et famille. Enquête sur les mesures proposées aux employé-e-s par les organisations privées et publiques de l'arc lémanique. 48. Retrieved from http://www.rezonance.ch/fs-search/download/ RapportVia2 14.12.2004.pdf?version_id=621040

Castles, F. G., \& Obinger, H. (2008). Worlds, families, regimes: Country clusters in European and OECD area public policy. West European Politics, 31(1-2), 321-344. doi:10.1080/01402380701835140.

Dafflon, B. (2003). La politique familiale en Suisse: enjeux et défis. Lausanne: Réalités sociales.

Deutsch, F. M. (2007). Undoing gender. Gender \& Society, 21(1), 106-127. doi:10.1177/0891243206293577.

European Union. (2010). Council Directive 2010/18/EU. Retrieved from http://eur-lex.europa.eu/ legal-content/EN/ALL/;ELX_SESSIONID=QL5TTfVNDw3khGSfWMDccbNlHpJzFQsGn VphWTpGGTwgyhJ7mTLD!-1004298186?uri=CELEX:32010L0018

FCWI. (2001). Femmes Pouvoir Histoire. Histoire de l'égalité en Suisse de 1848 à 2000. Berne: Swiss Confederation. Available at http://www.ekf.admin.ch/dokumentation/00444/00517/ index.html?lang=fr

FCWI. (2011). Femmes Pouvoir Histoire. Dès 2001. Berne: Swiss Confederation Available at http://www.ekf.admin.ch/dokumentation/00444/00516/index.html?lang=fr

FCWI. (2014). Congé parental. Bern: Federal Commission for Women's Issues (FCWI) Availabe at: http://www.ekf.admin.ch/dokumentation/00507/00648/index.html?lang=fr

FSIO. (2013). Congé de paternité et congé parental. Etat des lieux et présentation de divers modèles. Bern: Federal Department of Home Affairs.

FSO. (2008). Les familles en Suisse. Rapport statistique 2008. Neuchâtel: Federal Statistical Office.

FSO. (2013a). Egalité entre femmes et hommes - Données, indicateurs. Modèles d'activité professionnelle des couples. Retrieved from http://www.bfs.admin.ch/bfs/portal/fr/index/themen/20/05/blank/key/Vereinbarkeit/03.html 
FSO. (2013b). Proportion of live births outside marriage. Retrieved from http://www.bfs.admin. $\mathrm{ch} / \mathrm{bfs} / \mathrm{portal} / \mathrm{en} / \mathrm{index} / \mathrm{themen} / 01 / 06 / \mathrm{blank} / \mathrm{key} / 02 / 03$.html

Giudici, F., \& Gauthier, J.-A. (2009). Différenciation des trajectoires professionnelles liées à la transition à la parentalité en Suisse. Swiss Journal of Sociology, 35(2), 253-278.

Haas, L. (2003). Parental leave and gender equality: Lessons from the European Union. The Review of Policy Research, 20(1), 89-114. doi:10.1111/1541-1338.d01-6.

Haas, L., \& Hwang, P. C. (2008). The impact of taking parental leave on fathers' participation in childcare and relationships with children: Lessons from Sweden. Community, Work \& Family, 11(1), 85-104. doi:10.1080/13668800701785346.

Haas, L., \& Rostgaard, T. (2011). Fathers' rights to paid parental leave in the Nordic countries: Consequences for the gendered division of leave. Community, Work \& Family, 14(2), 177-195. doi:10.1080/13668803.2011.571398.

Häusermann, S., \& Kübler, D. (2010). Policy frames and coalition dynamics in the recent reforms of Swiss family policy. German Policy Studies, 6(3), 163-194.

Hojgaard, L. (1997). Working fathers - Caught in the web of the symbolic order of gender. Acta Sociologica, 40(3), 245-261. doi:10.1177/000169939704000302.

Huerta, M. d. C., Adema, W., Baxter, J., Han, W.-J., Lausten, M., Lee, R., \& Waldfogel, J. (2013). Fathers' leave, fathers' involvement and child development: are they related? Evidence from Four OECD Countries (OECD Social, Employment and Migration Working papers, No. 140, p. 67). Retrieved from http://www.oecd-http://dx.doi.org/10.1787/5k4dlw9w6czq-en

Lanfranconi, L. M., \& Valarino, I. (2014). Gender equality and parental leave policies in Switzerland. A discursive and feminist perspective. Critical Social Policy, 34(4), 538-560. doi:10.1177/0261018314536132.

Le Goff, J.-M., Levy, R., Sapin, M., \& Camenisch, M. (2009). Devenir parent: changer de vie? In M. Oris, E. Widmer, A. de Ribaupierre, D. Joye, D. Spini, G. Labouvie-Vief, \& J.-M. Falter (Eds.), Transitions dans les parcours de vie et construction des inégalités (pp. 211-232). Lausanne: Presses polytechniques et universitaires romandes.

Le Goff, J.-M., \& Ryser, V.-A. (2010). Meaning of marriage for men during their transition to fatherhood: The Swiss context. Marriage \& Family Review, 46(1), 107-125. doi:10.1080/01494921003648654.

Leimgruber, M. (2010). Protecting soldiers, not mothers: Soldiers' income compensation in Switzerland during World War II. Social Politics: International Studies in Gender, State \& Society, 17(1), 53-79. doi:10.1093/sp/jxp024.

Levy, R., Gauthier, J.-A., \& Widmer, E. (2006). Entre contraintes institutionnelle et domestique: les parcours de vie masculins et féminins en Suisse. Cahiers canadiens de sociologie, 31(4), 461-489. doi:10.1353/cjs.2006.0070.

Levy, R., Widmer, E., \& Kellerhals, J. (2002). Modern family or modernized family traditionalism?: Master status and the gender order in Switzerland. Electronic Journal of Sociology, 6(4). Retrieved from http://sociology.org/content/vol006.004/lwk.html

Lüdi, G., \& Werlen, I. (2005). Le paysage linguistique en Suisse. Neuchâtel: Office fédéral de la statistique (OFS).

Lupton, D., \& Barclay, L. (1997). Constructing fatherhood. Discourses and experiences. London: Sage.

Mach, A., \& Trampusch, C. (2011). The Swiss political economy in comparative perspective. In C. Trampusch \& A. Mach (Eds.), Switzerland in Europe. Continuity and change in the Swiss political economy (pp. 11-26). Oxon: Routledge.

Moss, P. (2008). Making parental leave parental: an overview of policies to increase fathers' use of leave. In P. Moss (Ed.), International review of leave policies and related research 2008 (Vol. Employment relations research series no. 100, pp. 79-84). London: BERR Department for Business Enterprise \& Regulatory Reform.

Moss, P. (Ed.). (2014). International review on leave policies and related research 2014. International Network on Leave Policies and Research: Available at: http://www.leavenetwork. org/fileadmin/Leavenetwork/Annual_reviews/2014_annual_review_korr.pdf 
Nentwich, J. C. (2008). New fathers and mothers as gender troublemakers? Exploring discursive constructions of heterosexual parenthood and their subversive potential. Feminism \& Psychology, 18(2), 207-230. doi:10.1177/0959353507088591.

Nepomnyaschy, L., \& Waldfogel, J. (2007). Paternity leave and fathers' involvement with their young children. Community, Work \& Family, 10(4), 427-453. doi:10.1080/13668800701575077.

O'Brien, M. (2009). Fathers, parental leave policies, and infant quality of life: International perspectives and policy impact. The ANNALS of the American Academy of Political and Social Science, 624, 190-213. doi:10.1177/0002716209334349.

Obinger, H. (1998). Federalism, direct democracy, and welfare state development in Switzerland. Journal of Public Policy, 18(3), 241-263.

Obinger, H., Armingeon, K., Bonoli, G., \& Bertozzi, F. (2005). Switzerland: The marriage of direct democracy and federalism. In H. Obinger, S. Leibfried, \& F. G. Castles (Eds.), Federalism and the welfare state. New world and European experiences (pp. 263-304). Cambridge: Cambridge University Press.

Pfau-Effinger, B. (2008). Cultural change and path departure: The example of family policies in conservative welfare states. In W. Van Oorschot, M. Opielka, \& B. Pfau-Effinger (Eds.), Culture and welfare state (pp. 185-204). Cheltenham: Edward Elgar.

Pleck, J. H. (1993). Are "family-supportive" employer policies relevant to men? In J. C. Hood (Ed.), Men, work, and family (pp. 217-237). Newbury Park: Sage.

Rehel, E. M. (2014). When dad stays home too: Paternity leave, gender, and parenting. Gender \& Society, 28(1), 110-132.

Risman, B. J. (1998). Gender vertigo: American families in transition. New Haven/London: Yale University Press.

Risman, B. J. (2004). Gender as a social structure: Theory wrestling with activism. Gender \& Society, 18(4), 429-450. doi:10.1177/0891243204265349.

Risman, B. J. (2011). Gender as structure or trump card? Journal of Family Theory \& Review, 3, 18-22. doi:10.1111/j.1756-2589.2010.00076.x.

SECO, \& FSIO. (2012). Plate-forme d'information "Conciliation travail-famille: Mesures cantonales et communales". Retrieved from http://www.berufundfamilie.admin.ch/informationsplattform/index.html? $\mathrm{v}=\&$ lang $=\mathrm{fr} \& \mathrm{~b}=3 \& \mathrm{e}=\& \mathrm{t} \% 5 \mathrm{~B} \% 5 \mathrm{D}=127$

Studer, B. (1997). Familienzulagen statt Mutterschaftsversicherung? Die Zuschreibung der Geschlechterkompetenzen im sich formierenden Schweizer Sozialstaat, 1920-1945. Schweizerische Zeitschrift für Geschichte, 47(2), 151-170.

Tanaka, S., \& Waldfogel, J. (2007). Effects of parental leave and work hours on fathers involvement with their babies. Community, Work \& Family, 10(4), 409-426. doi:10.1080/13668800701575069.

Tremblay, D.-G. (2014). Fathers and parental/paternity leave: The case of innovative, subversive and militant fathers in Québec. Paper presented at the International Workshop "Fathers on leave and gender equality: A comparative perspective", University of Lisbon.

Valarino, I. (2014a). The emergence of parental and paternity leaves in Switzerland: A challenge to gendered representations and practices of parenthood. $\mathrm{Ph} . \mathrm{D}$. in social sciences, University of Lausanne, Lausanne. Retrieved from http://serval.unil.ch/?id=serval:BIB_EC9A89C2A3A6

Valarino, I. (2014b). Switzerland: Country note. In P. Moss (Ed.), International review of leave policies and related research 2014. Available at http://www.leavenetwork.org/fileadmin/ Leavenetwork/Country_notes/2014/Switzerland.pdf

Valarino, I., \& Gauthier, J.-A. (2015). Paternity leave implementation in Switzerland: A challenge to gendered representations and practices of fatherhood? Community, Work \& Family, 21. doi:http://dx.doi.org/10.1080/13668803.2015.1023263

Wall, K. (2014). Fathers on leave alone: Does it make a difference to their lives? Fathering, 12(2), 196-210. 
West, C., \& Zimmerman, D. H. (1987). Doing gender. Gender and Society, 1(2), 125-151. doi:10 $.1177 / 0891243287001002002$.

Widmer, E., Levy, R., Pollien, A., Hammer, R., \& Gauthier, J.-A. (2003). Entre standardisation, individualisation et sexuation: une analyse des trajectoires personnelles en Suisse. Revue Suisse de Sociologie, 29(1), 35-67. Retrieved from http://www.sgs-sss.ch/fr-revue

Open Access This chapter is licensed under the terms of the Creative Commons AttributionNonCommercial 2.5 License (http://creativecommons.org/licenses/by-nc/2.5/), which permits any noncommercial use, sharing, adaptation, distribution and reproduction in any medium or format, as long as you give appropriate credit to the original author(s) and the source, provide a link to the Creative Commons license and indicate if changes were made.

The images or other third party material in this chapter are included in the chapter's Creative Commons license, unless indicated otherwise in a credit line to the material. If material is not included in the chapter's Creative Commons license and your intended use is not permitted by statutory regulation or exceeds the permitted use, you will need to obtain permission directly from the copyright holder.

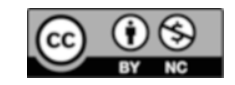

